10 years ESJ

Special edition

\title{
Anti-Drug Policies in Different Countries and Georgia: Current Situtation and Challenges
}

\author{
Shota Tkeshelashvili \\ Grigol Robakidze University, Georgia
}

Doi:10.19044/esj.2022.v18n5p75

Submitted: 11 November 2021

Accepted: 16 December 2021

Published: 21 February 2022
Copyright 2022 Author(s)

Under Creative Commons BY-NC-ND

4.0 OPEN ACCESS

Cite As:

Tkeshelashvili S. (2022). Anti-Drug Policies in Different Countries and Georgia: Current Situtation and Challenges. European Scientific Journal, ESJ, 18 (5), 75.

https://doi.org/10.19044/esj.2022.v18n5p75

\section{Abstract}

Problems with illegal drug circulation have even become a destabilizing factor for many countries. Therefore, the topic under consideration is undoubtedly problematic. The present article according to qualitative research method focuses on the current situation, challenges and ways of solving problems regarding the drug policy in Georgia and some foreign countries. The research has shown that the problems connected to the drugs (use, sale, transportation and etc) are common to many countries and according to the existing reality, it will probably be a topic issue for a long time not only for Georgia, but also in many countries around the world. Determination of effective drug policy in Georgia is one of the most pressing problems and tasks, but resolving of issue of adequate and proper responsibility for drug use is the most urgent matter.

Keywords: Drug policy, drug crime, drugs, anti-drug politics

\section{Introduction}

The social threat of drug use is not limited only with the material loss of society. Problems with illegal drug circulation have even become a destabilizing factor for many countries. Therefore, the topic under consideration is undoubtedly problematic. The relevance of the topic is determined by its theoretical and practical significance. The spread of drugs around the world has many reasons: political, economic, social, legal and 
moral. Consequently, it is necessary to understand these causes, identify them and find adequate ways to eliminate them. The government should make every effort to minimize the sale of drugs and ensure that the country was not an open and fertile ground for drug trafficking.

It is important that the state should not deprive drug users of their right to privacy and freedom of work. Their stigmatization and discrimination are unacceptable. The state should provide their treatment, and it is available to absolutely everyone who wants and understands how to solve their problem. Furthermore, it is necessary to establish a different approach and responsibility for the use of drugs of different types and forces, as well as for the frequency of use. If the state does not develop a drug policy based on human rights, it will not just be powerless, but on the contrary, will aggravate the situation in the country. A key feature of the approaches of foreign countries is not focusing on the problem and its elimination, but on the recognition of the problem and the implementation of a pragmatic and realistic strategy towards it, which, if actualizing, leads to effective problem management (State Strategy against drugs).

Therefore, the aim of the article is to find out which kinds of processes of fighting and which methods are used to solve the problem of drug addiction, as in Georgia, so in some foreign countries.

\section{Materials and Methods}

The research was conducted using materials provided from policies, reports, laws and official statistics (analyzing statistics regarding Ministry of Internal Affairs, the Ministry of Justice of Georgia). The case study method was also used to focus on qualitative data using methods such analysis of primary and secondary sources.

\section{Georgian Legislation and Court Decisions on Drug Crimes}

In the last century, the war on drugs was considered the only way to overcome the drug problem in the world. And in the 21 st century, the effectiveness of the anti-drug paradigm was questioned, especially after the publication of the Global Commission on Drug Policy in June 2011 (The Global Commission on Drug Policy, n.d). The $21^{\text {st }}$ century brought awareness of the matter of necessity for a balanced drug strategy based on human rights, as well as scientific evidence, that is being implemented with particular consistency in the EU countries, which has stopped the scale of the problem in these countries (The European Monitoring Center for Drugs and Drug Addiction, n.d).

According to the approximate estimates, 200 million people worldwide use different types of drugs. The most common drug is cocaine, which is used by 13 million people and heroin - by 8 million people. 
Analyzing the number of drug crimes in the world, it was recorded that the number of drug crimes reaches 285 thousand. Among them, a large proportion of crimes are committed by drug users. The annual turnover of the global pharmaceutical industry at the UN is about 400 billion dollars. It is valued in US dollars and accounts for $8 \%$ of total international trade. (Mosulishvili, 2009).

Research of the researches center "Alternative Georgia" was implemented at the end of 2015, 4.805 thousand people were interviewed, $55.7 \%$ of whom were women. The age of respondents ranged from 18 to 65 years. According to the survey, $10.4 \%$ of respondents aged 18-24 years tried cannabis at least once in their lives, $4 \%$ - last year and $1 \%$ - in the last month. Only $0.6 \%$ of respondents said they had injected drugs at least once in their lives (Karchava, n.d).

Drug use killed almost half a million people in 2019, while drug use disorders resulted in 18 million years of healthy life lost, mostly due to opioids. Serious and often lethal illnesses are more common among drug users, particularly those who inject drugs, many of whom are living with HIV and Hepatitis C. Despite the proven dangers, drug use persists and, in some contexts, proliferates. Over the past year, around 275 million people have used drugs, up by 22 per cent from 2010. By 2030, demographic factors project the number of people using drugs to rise by 11 per cent around the world, and as much as 40 per cent in Africa alone (COVID-19 AND DRUGS: IMPACT OUTLOOK, World Drug Report, 2021).

According to the official website of the Ministry of Justice of Georgia, the fight against drug abuse is one of the priorities of the Georgian Government and the Ministry of Justice. In the process of developing the governmental policy for combating drug abuse the Ministry gives full consideration to the international standards. To enable the creation of effective and coordinated institutional mechanism, in 2011 an Inter-Agency Coordinated Council on Combating Drug Abuse was created (Ministry of Justice - Anti-drugs policy).

Over the years, injection drug use has been the primary route of HIV transmission in Georgia. As of 1 December 2011, 3,080 AIDS cases had been reported in Georgia, 55.6 per cent of which had been transmitted through injecting drug use. The main route of HIV transmission in 2012 was injection drug use (366 new cases, 54.9\% injection) (Gorgodze, Gamisonia, n.d.).

Currently there are four clinics providing residential drug dependence treatment in Georgia, three of which are based in Tbilisi and one in Batumi. There are 17 programmes for the replacement of opiate agonists, serving a total of about 2,300 patients per year (National drug strategy).

According to the Criminal Legislation of Georgia, particularly, the crime considered by the part I of the article 260 of Criminal Code of Georgia, 
which means illegal manufacturing, production, purchase, storage, transportation, transfer or sale of drugs, their analogues or precursors, shall be punished by imprisonment for up to six years. According to the $6^{\text {th }}$ part of the same article, in case of existence of aggravating factors: in particularly large quantities; by an organized group shall be punished by imprisonment for a term of eight to twenty years or by life imprisonment (Criminal Code of Georgia, 1999).

According to article 273 of Criminal Code of Georgia, illegal production, purchase, storage, carrying, transfer or illegal consumption without medical prescription of a narcotic drug, its analogue or a precursor in small quantity, committed by a person who was subjected to an administrative penalty for committing an administrative offence under Article 45 of the Administrative Offences Code of Georgia, or who was convicted for this crime, - shall be punished by a fine or community service from 120 to 180 hours or by imprisonment for up to one year (Criminal Code of Georgia, 1999).

Generally, has to be mentioned, that legislation on drug crime in Georgia has undergone some changes in terms of punishment and mitigation of punishment. This was caused by decisions of the Constitutional Court, which accelerated the process of amending the legislation accordingly.

The following decisions of the Constitutional Court have the following importance:

According to the Decision of the Constitutional Court dated October 24, 2015, a normative content of the wording which sets imprisonment as a punishment for purchase-possession for personal use of narcotic substance dried Marijuana up to 70 grams, was declared unconstitutional (Decision of the Constitutional Court from October 24, 2015).

According to the Decision of the Constitutional Court dated July 30, 2018, a normative content of the wording "and/or use without a doctor's prescription" of section 1 of Article 45 of Administrative Offences Code of Georgia which sets punishment for use of narcotic substance - marijuana in the absence of appropriate circumstances was declared unconstitutional (Decision of the Constitutional Court from July 30, 2018).

According to the Decision of the Constitutional Court from June 4, 2020, a normative content of the wording of part 3 of article 260 of the Criminal Code of Georgia, which provided for the possibility of deprivation of liberty as a punishment for the illegal acquisition and possession of narcotic drugs in unsuitable quantities, was declared unconstitutional (Decision of the Constitutional Court from June 4, 2020). 


\section{International experience in drug policy management}

Portugal - Portugal decriminalised the possession and possession for personal use of all drugs in 2001. As a result, consumption in teens decreased. At such a sensitive age as 15-24 years, after the reform, there is a steady decline in consumption, and problematic consumption is declining. There has been a decrease in consumption in groups that inject drugs or have a strong dependence. The number of problem users involved in treatment has also increased significantly. The number of new cases of HIV/AIDS has decreased significantly. As a result of the expansion and decriminalization of harm reduction programs, the significantly increased participation of consumers in medical and social programs almost completely eliminated the risk of infection by injection, as well as reduced the rate of overdose deaths. Due to the decriminalization, these harm reduction programmes have become widely available. In 2001-2012, the overdose mortality rate decreased almost 10 times (from 80 to 18 people). (Assessment of the impact of drug policy reform in Georgia, 2017).

Germany - In Germany, the National Strategy on Drug and Addiction Policy was adopted in 2012. The strategy is based on four pillars: prevention, counselling, treatment and help in overcoming addiction, harm reduction measures and supply reduction. Prevention interventions encompass a wide range of approaches, which are complementary. Environmental and universal strategies target entire populations, selective prevention targets vulnerable groups that may be at greater risk of developing substance use problems and indicated prevention focuses on at-risk individuals. Environmental prevention measures focus on restricting smoking in public places, banning sales of tobacco products and alcohol to minors, enforcing punishment for driving under the influence of psychoactive substances and implementing police measures to reduce the availability of illicit drugs in general. Prevention programs oriented towards families aim to increase parenting skills (Strengthening Families Programme), build the protective role played by the family and strengthen the basic life skills of the children.

From the selective prevention measures has to be mentioned FReD goes net29 - Program for young drug users, introduced in 10 European Union countries. There is also a Family Support Therapy pilot programme for young at-risk drug users and their families, which helps parents of drug-dependent young people manage family relationships and provide timely assistance to young people. Harm reduction measures serve to reduce the mortality and morbidity of drug users.

Germany is among the few European countries that provide the full range of harm reduction services, along with needle and syringe programmes; take-home naloxone programmes for overdose prevention, supervised drug 
consumption rooms and heroin-assisted treatment (Assessment of the impact of drug policy reform in Georgia, 2017).

France - The French Government plan to fight drugs and drug addiction was based on five basic principles: prevention, care and risk reduction; fighting against the trafficking; improving law enforcement; establishment of the fight against drugs and drug addiction based on the analytical studies; strengthening coordination at the national and international levels. Between the preventive measures, universal and selective strategies should be noted. Implementation of the universal strategy starts from the middle schools, where are used the best guidelines developed by the National Institute for Prevention and Health Education - INPES. The main goal of school prevention activities is to develop the individual and social skills of pupils and students to handle with drug use. Selective prevention is mainly carried out by non-governmental organizations outside the schools, recreation centres and at-risk families. In entertainment centres, educators of children and youngs have been trained to respond to addictive behaviour and educational activities.

In France, from four harm reduction programs implemented in European countries, are active three programs: needle and syringe programmes; take-home naloxone programmes for overdose prevention, supervised drug consumption rooms are used. The use and possession of banned drugs is a criminal offence. According to the law, it does not matter whether the drug is used for personal purposes or for sale, also the type of substance does not matter. Nevertheless, the prosecutor is empowered to determine the purpose of drug use or sale depending on the amount of drugs in the sentence, and he/she decides whether to take measures - to initiate criminal proceedings, close the case or decides taking other alternative measures (Assessment of the impact of drug policy reform in Georgia, 2017).

Hungary - The National Anti-Drug Strategy 2013-2020 is aimed at the inhibited drugs and is based on five principles: 1. right to life, dignity and health; 2. personal and public liability; 3. public involvement; 4.cooperation; 5. relying on evidence. The National Anti-Drug Strategy establishes objectives and development directions at three intervention areas: 1) health development, drug prevention; 2) treatment, care, recovery; 3) supply reduction. Nongovernmental organizations and police implement preventive measures and universal prevention activities in the educational institutions. Only programs recommended by the National Institute for Health Development (NEFI), which is responsible for accreditation and monitoring of preventive measures in schools, are allowed.

In recent years, programs have become more interactive and are aimed at influencing the views and values of the target audience. Selective prevention measures are aimed at young people who are placed in penitentiary 
institutions, live in an unfavourable environment and are homeless. Attention is paid to families in need. The purpose of prevention programs is to help young people at risk, students with special needs and family members with drug problems to develop the skills necessary for family relations (Assessment of the impact of drug policy reform in Georgia, 2017).

Belgium - The drug policy of Belgium is defined in two key policy documents: the Federal Drug Policy Note of 2001 and the Common Declaration of 2010. The Federal Drug Policy Note was adopted as a longterm policy document and focuses on both illicit and licit substances, including alcohol, tobacco and psychoactive medicines. The main goals of this document are the prevention and reduction of risks for people who use drugs, the environment and society as a whole; these goals are organised across three pillars: prevention and early intervention in drug consumption; harm reduction, treatment and reintegration; and enforcement. The Federal Drug Policy Note also states the five main principles of Belgian drug policy, which are (i) a global and integrated approach; (ii) evaluation, epidemiology and scientificresearch; (iii) prevention for non-users and problematic drug users; (iv) treatment, risk reduction and reintegration for problematic users; and (v) repression of producers and traffickers. The Common Declaration is a further statement and confirms the approach set out in the Federal Drug Policy Note. Given this, it can be considered a more up-to-date elaboration of Belgian drug policy.Belgium evaluates its drug policy and strategy through routine indicator monitoring and specific research projects, in a similar way to other European countries. The evaluation of specific interventions and projects is one of the objectives of the Drug Research Program of Federal Science Policy. (Belgium Country Drug Report, 2019). 
European Scientific Journal, ESJ ISSN: 1857-7881 (Print) e - ISSN 1857-7431 February 2022

Bridging Language, Medicine, and Law

Diagram 1 - Drug Related Crimes in Belgium 2008-2019

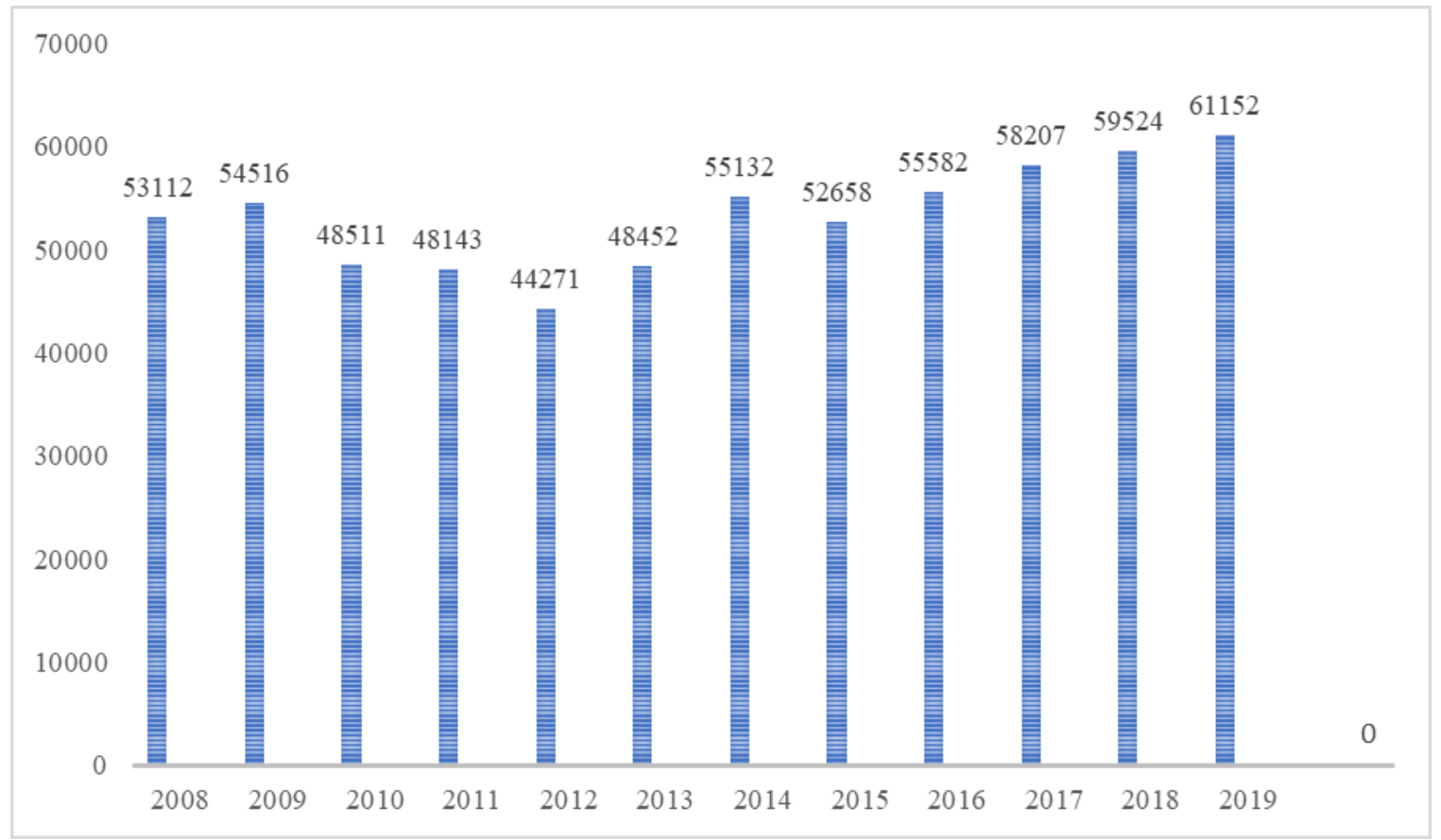

Note - Federal Police Belgium. Statista

\section{Results}

In order to see the current situation it is important to compare 2019 and 2020, drug related crimes statistics (table 1 and diagram 1)

Table 1- Drug Related Crimes of Georgia

\begin{tabular}{|c|c|c|c|c|c|c|c|}
\hline Crime & 2019 & $\begin{array}{c}\text { opened } \\
\text { cases }\end{array}$ & $\%$ & 2020 & $\begin{array}{c}\text { opened } \\
\text { cases }\end{array}$ & $\%$ & Change $\%$ \\
\hline $\begin{array}{c}\text { 260, 261-III-IV, 262, 263-III-IV, } \\
\text { 264-II-IV, 265-II-III, 266. 267. } \\
\text { 268-II-III, 271-III-IV, 272-II-III. }\end{array}$ & 3979 & 3169 & $79.64 \%$ & 2195 & 1716 & $78.18 \%$ & $-44.84 \%$ \\
\hline $\begin{array}{c}\text { Drug smuggling c. 262 } \\
\text { Purchase, storage or sale of } \\
\text { drugs c. 260 }\end{array}$ & 3239 & 2539 & $78.39 \%$ & 1719 & 1281 & $74.52 \%$ & $46.93 \%$ \\
\hline $\begin{array}{c}\text { Smuggling of psychotropic } \\
\text { drugs c. 263 }\end{array}$ & 20 & 6 & 30 & 2 & 1 & 50 & $-90 \%$ \\
\hline $\begin{array}{c}\text { Purchase, storage, sale of } \\
\text { psychotropic drugs c. 261 }\end{array}$ & 140 & 97 & $69.29 \%$ & 52 & 40 & $76.92 \%$ & $-62.86 \%$ \\
\hline $\begin{array}{c}\text { Illegal sowing of plants } \\
\text { containing drugs c. 265 }\end{array}$ & 797 & 727 & $91.22 \%$ & 563 & 529 & $93.96 \%$ & $-29.36 \%$ \\
\hline Repeated use of drugs c.273, 273 & 2004 & 1499 & $74.8 \%$ & 1042 & 857 & $82.25 \%$ & $48 \%$ \\
\hline $\begin{array}{c}\text { The rest of the c. 264, 266-272, } \\
\text { 274 }\end{array}$ & 17 & 10 & $58.82 \%$ & 10 & 2 & $20 \%$ & $41.18 \%$ \\
\hline sum & $\mathbf{6 4 1 5}$ & $\mathbf{4 9 8 9}$ & $\mathbf{7 7 . 7 7 \%}$ & $\mathbf{3 4 5 2}$ & $\mathbf{2 7 4 2}$ & $\mathbf{7 9 . 4 3 \%}$ & $\mathbf{+ 7 . 6 6 \%}$ \\
\hline
\end{tabular}

Note - Author, according to Ministry of Internal Affairs of Georgia 
As table 1 demonstrates, crimes have reduced in 2020 and the percentage of opened cases in $79.43 \%$, which actually is not low. Also it interesting to compare 2020 with 2021 (diagram 2).

Diagram 2 - Drug Related Crimes in Georgia

(period 01.01.2020 - 30.06.2020 / 01.01.2021 - 30.06.2021)

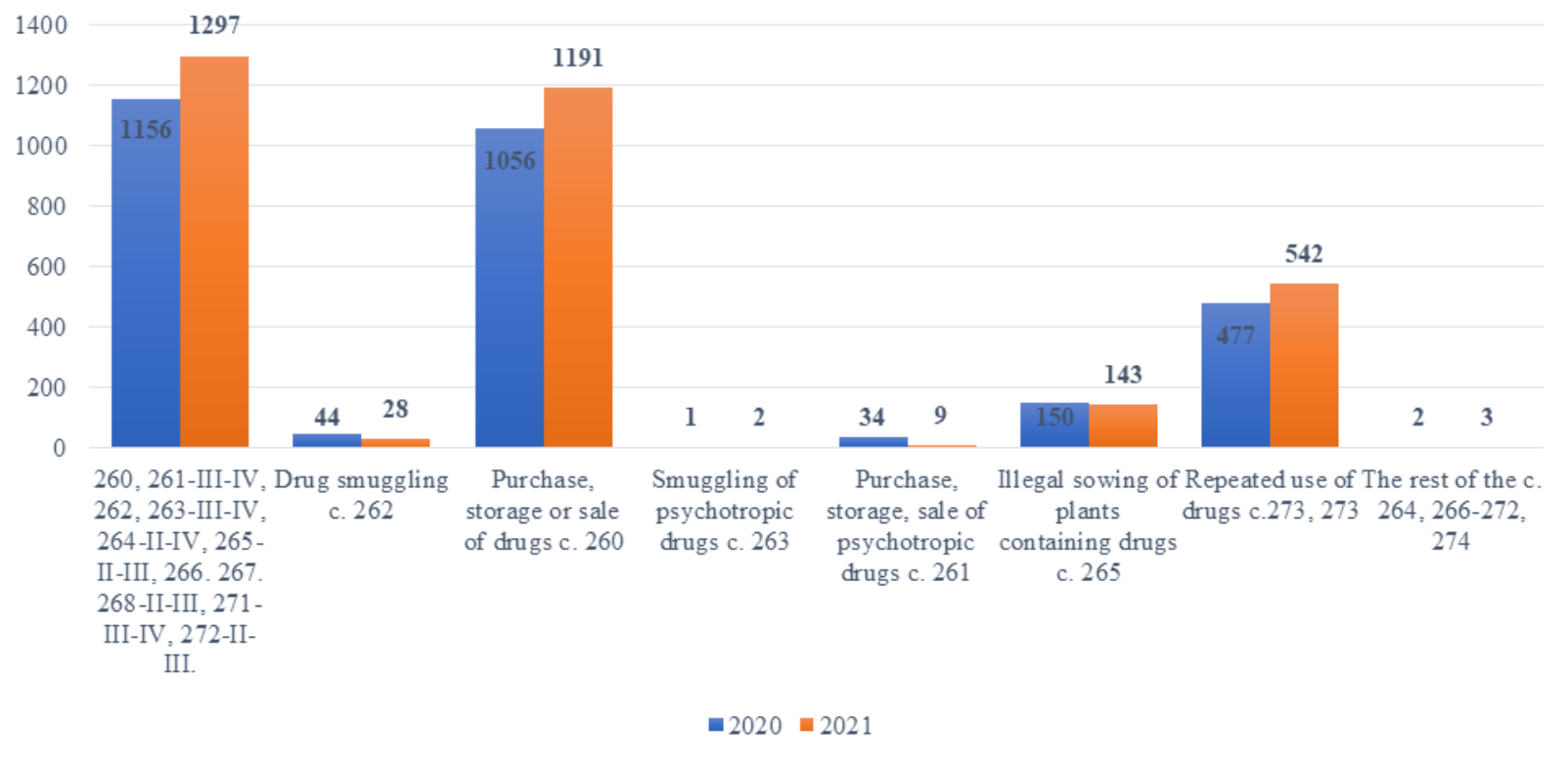

Note - Author, according to Ministry of Internal Affairs of Georgia

The quantity of drug related crimes in (period 01.01.2020 30.06.2020) is 1764 and in 2021 ( 01.01.2021 - 30.06.2021) - 1918. The drug related crimes for the same period has already grown with $+8.73 \%$, which actually is a serious problem.

The findings of this study indicate, that according to the discussed reports and policies problems for Portugal, Germany, France, Hungary, Belgium and Georgia are common and countries need to take into account the protection of public security, promotion of harmonious personal development, respect for privacy and human dignity, not only in other areas, but also in drug policymaking.

Table 2 - Important actions of the countries against drugs

\begin{tabular}{|c|l|c|}
\hline Country & \multicolumn{1}{|c|}{ Action } & Year \\
\hline Portugal & $\begin{array}{l}\text { Portugal decriminalised the possession and possession } \\
\text { for personal use of all drugs. }\end{array}$ & 2001 \\
\hline Germany & The National Strategy on Drug and Addiction Policy. & 2012 \\
\hline France & $\begin{array}{l}\text { France is a signatory to the 1925 Geneva Convention on } \\
\text { drugs, and accordingly banned cannabis as a medical }\end{array}$ & 1925 \\
& $\begin{array}{l}\text { treatment in 1953. Since then, the importation, sale, } \\
\text { transport and production of cannabis and cannabinoids } \\
\text { has been illegal in France. Public or private drug use }\end{array}$ & 1953 \\
\hline
\end{tabular}




\begin{tabular}{|c|l|c|}
\hline & $\begin{array}{l}\text { in France is prohibited and criminalized by the Law of } \\
1970 \text { (article L3421-1 of the Code of Public Health). }\end{array}$ & \\
\hline Hungary & The National Anti-Drug Strategy & $2013-2020$ \\
\hline Belgium & $\begin{array}{l}\text { The drug policy of Belgium is defined in two key policy } \\
\text { documents: the Federal Drug Policy Note of and the } \\
\text { Common Declaration. }\end{array}$ & 2001 \\
\hline Georgia & $\begin{array}{l}\text { The first criminal codes (Criminal Code of Georgia and } \\
\text { the codes of the other allied republics) did not contain a } \\
\text { special norm that directly provided for criminal liability } \\
\text { for drug-related crimes }\end{array}$ & 1922 \\
& $\begin{array}{l}\text { The Presidium of the Supreme Council issued a decree } \\
\text { "On establishing responsibility for the use of narcotics } \\
\text { and strengthening the fight against the theft (theft), illicit } \\
\text { manufacture and sale of these substances." }\end{array}$ & \multirow{2}{*}{$\begin{array}{c}2020 \\
\text { The National Strategy for the Prevention of Drug Abuse } \\
\text { 2021-2026. The strategy was initiated by the Interagency } \\
\text { Council on Drug Abuse and the Ministry of Justice of } \\
\text { Georgia with the support of the EU project "EUACT: EU } \\
\text { Actions Against Drugs and Organized Crime" }\end{array}$} \\
\hline
\end{tabular}

Note - Author, according to the discussed literature

As table 2 demonstrates Conventions became more actual for the countries in earlier period, then countries have created their Codes and later policies, in order to have more active and aggressive campaigns against drug related crimes. It should be mentioned that The National Strategy of Georgia for 2021-2026, is very important and hopeful, because it includes all important cases and issues, which will help the country to reduce drug related crimes, support humans and work on the prevention at school too. As the research showed, polices have positive effect on a long time period and not immediately, so the results of the strategy will be visible in next 5-10 years.

\section{Conclusion}

While defining drug policies, states often choose between a repressive or human rights-based approach. States need to take into account the promotion of harmonious personal development, protection of public security, respect for privacy and human dignity, not only in other areas, but also in drug policymaking. Also, the promotion of public information and education. Since it has long been known that the problem of drug use cannot be eliminated, regardless of whether the state has strictly punitive or liberal policy, the most important issue is to ensure, that drug use causes minimal harm to the society. Thus, the analysis of foreign legislation discussed in the present article shows that the drug policies of the abovementioned countries are aimed at preventing crime, caring for drug users and reducing risks. Alike in foreign countries, in accordance with constitutional decisions and changes in legislation, Georgia took an active part in creating a favorable legal environment for treatment, 
rehabilitation and harm reduction, as well as adhering to liberal approaches to drug users. It has to be noted, that a methadone replacement therapy program has been launched in Georgia, which is absolutely free for patients. The decision increased the number of beneficiaries involved in the program. Despite the above-mentioned reforms, in order to fully implement the goals of the state strategy against drugs, it is also necessary to amend the legislation accordingly, after which our country's drug policy, like that of foreign countries, will become more flexible and preventive.

\section{References:}

1. Belgium Country Drug Report (2019). The European Monitoring Centre for Drugs and Drug Addiction. Retrieved August 11, 2021, from:https://www.emcdda.europa.eu/system/files/publications/11345/ belgium-cdr-2019_0.pdf

2. Committee on Health Care and Social Affairs of the Parliament of Georgia (2017). "Assessing the Impact of Regulation of Drug Policy Reform in Georgia" pp.149, pp.151-152; Pp. 153-154. Retrieved August 11, 2021, from https://grass.org.ge/wp-content/uploads/2018/02/narkopolitikaRIA.pdf

3. Constitutional Court. Decision of the Constitutional Court on October 24, 2015. Politics. Retrieved August 11, 2021, from https://www.constcourt.ge/ka/judicialacts?legal $=1043 \&$ scrollheight $=300$;

4. Constitutional Court. Decision of 30 July 2018. Retrieved August 11, 2021, from

https://www.constcourt.ge/ka/judicialacts? legal $=1949 \&$ scrollheight $=8382 ; 0$

5. Constitutional Court. Decision of 4 June 2020. Retrieved August 11, 2021, from https://www.constcourt.ge/ka/judicialacts?legal $=9494 \&$ scrollheight $=7416$;

6. COVID-19 AND DRUGS: IMPACT OUTLOOK, World Drug Report, (2021). Retrieved August 11, 2021, from https://www.unodc.org/res/wdr2021/field/WDR21_Booklet_5.pdf

7. Criminal Code of Georgia. (1999). Retrieved August 11, 2021, from https://www.matsne.gov.ge/ka/document/view/16426?publication=23 5

8. Drug-related crimes in Belgium 2008-2019. https://www.statista.com/statistics/534926/drug-related-crimes-inbelgium/ 
9. The Global Commission on Drug Policy (n.d). Retrieved August 11, 2021, from https://www.globalcommissionondrugs.org/

10. Gorgodze S. Gamisonia D. (n.d). "Prevention and Repressive Drug Policy.

11. The European Monitoring Centre for Drugs and Drug Addiction.(n.d) Retrieved August 11, 2021, from http://www.emcdda.europa.eu/news/home.

12. Karchava Sh. (n.d). "Drug Policy Liberalization in Georgia - Expected Threat and Real Figures". Retrieved August 11, 2021, from www.dlmn.info.ge

13. Ministry of Internal Affairs of Georgia. Retrieved August 11, 2021, from https://info.police.ge/page?id=560\&parent_id=115

14. Ministry of Justice of Georgia - Anti-Drug Policy. Retrieved August 11, 2021, from http://www.justice.gov.ge/ministry/Department/308

15. Mosulishvili A. (2009). "Criminological characterization of drug addiction and aspects of combating it."

16. State Strategy for Combating Drug Addiction. Georgia. Retrieved August 11, 2021, from https://test.ncdc.ge/Pages/User/LetterContent.aspx ?ID=557b9ee2ab6c-4631-9843-558c55677061 